\title{
ESTUDO DA SITUAÇÃO SÓCIO-ECONOMICA E DO CONSUMO DE NUTRIENTES EM COMUNIDADES DO VALE DO RIBEIRA, SÃO PAULO, BRASIL *
}

\author{
Ignez Salas MARTINS **
}

\section{RSPSP-132}

Martins, I. S. - Estudo da situação só. cio-económica e do consumo de nutrientes em comunidades do Vale do Ribeira, Sẫo Paulo, Brasil. Rev. Saúde públ., S. Paulo, 6:199-209, 1972.

Resumo: Foi feito um levantamento da renda total anual por família e da renda "per capita" média anual por fami. lia, em três comunidades do Vale do Ribeira. Houve a necessidade de se adaptar o método de investigação às condições locais de vida, no sentido de se obter resultados mais condizentes com a realidade. Duas das comunidades estudadas, as de Vila de Icapara e de Pontal do Ribeira, possuem economia de subsistência e suas populaçóes vivem da pesca e da agricultura. $A$ terceira é formada por diaristas de Iguape vivendo em centro urbano, a cidade de Iguape. Nessas comunidades fez-se também um inquérito alimentar, pelo método das pesagens e calculou-se a adequação do consumo de nutrientes e de calorias entre as familias. Calculou-se o coeficiente de correlação de Pearson entre variáveis económicas e a adequação do consumo de proteinas e de calorias, chegando-se aos resultados: a) Nas duas comunidades que possuem economia de subsistência, Vila de Icapara e Pontal do Ribeira, não houve correlação entre consumo de proteinas $e$ de calorias, $e$ o nivel econômico $f a$ - miliar. b) Entre os diaristas de Iguape, encontrou-se uma correlação positiva entre consumo de proteinas e de calorias e nivel econômico familiar.

UNITERMOS: Inquérito sócio-econômi$\mathrm{co}^{*}$; Nutrientes, consumo"; Inquérito alimentar*.

\section{$1-$ I N T RODU ÇÃ O}

Quando se analisam as causas de desnutrição protéica em populações, impõese como uma das principais, o baixo poder aquisitivo desses grupos populacionais. Em zonas porém, onde a proteína animal é suficientemente disponível, como acontece em algumas economias de subsistência, se houver baixo consumo de proteínas poder-se-á pensar que; nessas zonas, a barreira econômica não constitui fator causal relevante. Quando uma comunidade dispõe de alimentos e não os aproveita, assim procede, ou por desconhecer a importância nutricional desses gêneros ou por estar presa a tabús alimentares.

Foi feito um estudo em três comuni-

* Resumo da monografia apresentada à Comissão Julgadora do Concurso de Mestrado em Nutricão em Saúde Pública no Departamento de Nutrição da Faculdade de Saúde Pública da USP. Trabalho realizado como parte dos programas do Departamento de Nutrição, em virtude do sub-convênio celebrado entre a Faculdade de Saúde Pública da USP e o Serviço do Vale do Ribeira, então órgão do Departamento de Aguas e Energia Elétrica (DAEE), em 1970.

** Do Departamento de Nutrição da Faculdade de Saúde Pública da USP - Av. Dr. Analdo, 715, São Paulo, S.P., Brasil. 
MARTINS, I. S. - Estudo da situação sócio-econômica e do consumo de nutrientes em comunidades do Vale do Ribeira, São Paulo, Brasil. Rev. Saúde públ., S. Paulo, 6: 199-209, 1972.

dades do Vale do Ribeira, litoral sul de São Paulo. Duas delas, as Vilas de Icapara e de Pontal do Ribeira, à primeira vista podem ser consideradas como zonas em que a disponibilidade de alimentos protéicos de origem animal é grande, uma vez que, sendo comunidades ribeirinhas, suas populações vivem da pesca e da agricultura de subsistência. A terceira comunidade estudada foi constituída pelos diaristas de Iguape que, como as populações de vila de Icapara e Pontal do Ribeira, vivem da produção diária irregular e inconstante, porém está inserida em um centro urbano. Durante 6 meses do ano, grande parte dos diaristas empregam-se como pescadores ou como trabalhadores na industrialização do pescado.

E objetivo deste trabalho, estudar o nível sócio-econômico das populaçōes referidas e a adequação do consumo de nutrientes e de calorias e, ainda, analisar até que ponto a barreira econômica interfere no consumo de proteínas e de calorias.

\section{1 - Caracteristicas das três comu- nidades:}

Pontal do Ribeira, Vila de Icapara e Iguape, estão situadas a, aproximadamente, $160 \mathrm{~km}{ }^{1}$ da capital de São Paulo, no Vale do Ribeira.

As Vilas de Icapara e Pontal do Ribeira, pelas suas características, tais como pauperismo aparente, padrão alimentar e condiçóes culturais, muito se assemelham às comunidades litorâneas das áreas mais desprotegidas do norte e nordeste do país. Pertencem ao município de Iguape, sendo a Vila de Icapara banhada pela mistura das águas do Rio
Ribeira e do Mar Pequeno e, a de Pontal do Ribeira, pelas águas do Rio Ribeira, Suamirim e as do Atlântico Sul.

O número de habitantes de vila de Icapara é de 485 pessoas, agrupadas em 103 famílias e o de Pontal do Ribeira, 206 pessoas distribuídas em 56 famílias ${ }^{5}$.

Em Vila de Icapara, de outubro a março, temporada de pesca da manju$\mathrm{ba}^{*}$, os pescadores passam a ser assalariados e, portanto, dependentes dos industriais de Iguape, que lhes fornecem, também, todo o material de trabalho embora inexista contrato escrito de trabalho entre os pescadores e os industriais.

Em Pontal do Ribeira, pesca-se principalmente o robalo (Mugil capito) e a tainha (Oxilabrax undecimales) e a pesca, na sua quase totalidade, é realizada por conta própria. Os pescadores vendem seus produtos a comerciantes locais ou ao consumidor de Iguape.

As populações destas duas comunidades cultivam em grande escala a rama (mandioca) e em menor, o arroz e o feijão. Seus alimentos básicos são o peixe e a farinha de mandioca de fabricação caseira.

A cidade de Iguape está localizada entre o Mar Pequeno e o Valo Grande do Rio Iguape, tendo em frente a Ilha Comprida. Esse município conheceu época florescente. " $\mathrm{Em} 1695$ os Iguapenses usavam ouro em pó nas suas transações comerciais. No século XVIII a cidade atingiu seu esplendor. Nela construiram-se suntuosas mansões senhoriais" 4.

Dentro dos vestígios do passado, encontra-se agora, uma economia estacionária tentando nova fase de desenvolvi-

* Manjuba ou "enchova" - nome popular dos peixes da família Engraulidae. O gênero mais típico dos nossos mares é Anchovia, com talvez 10 espécies. 
MARTINS, I. S. - Estudo da situação sócio-econômica e do consumo de nutrientes em comunidades do Vale do Ribeira, São Paulo, Brasil. Rev. Saúde públ., S. Paulo, 6: 199-209, 1972.

mento e uma população quase que totalmente desprovida de recursos médicos e sanitários.

Dentre a população de 7.269 pessoas distribuídas em 1.375 famílias, $23,9 \%$ delas vivem da renda obtida em pequenos serviços. Como já nos referimos, são diaristas que na temporada da pesca em. pregam-se nas indústrias de Iguape, sem algum contrato escrito de trabalho, como ocorre com os de Vila de Icapara. Os que não se dedicam à pesca são trabalhadores da Prefeitura, pedreiros, pin. tores, etc.

Os alimentos básicos desses diaristas, são o arroz, o feijão e, em menor proporção, o peixe e a carne.

\section{2 - Hábitos alimentares e adequa- ção do consumo de nutrientes:}

Foi feito pelos nutricionistas do Departamento de Nutrição um inquérito alimentar, pelo método das pesagens, em que se mediram as quantidades de alimentos que as familias amostradas nas três comunidades consumiram, em 24 horas.

Para o cálculo das necessidades de cada nutriente por família, foram seguidas as normas estabelecidas pela FAO (Food and Agriculture Organization of the United Nations) 2, 3.

Em Pontal do Ribeira os minerais e as vitaminas foram consumidos em quantidades deficientes pela totalidade das familias (Tabela 1). Quanto às proteínas, haviamos pressuposto, por se tratar de zona de pesca, que seu consumo seria satisfatório. Notou-se, porém, que $57,1 \%$ das famílias, têm um consumo abaixo de $100,0 \%$ de adequação e $32,7 \%$ em níveis acima de $120,0 \%$. O consumo de calorias foi abaixo de 100,0\% em 55,3\% das famílias e acima de $120,0 \%$ em $23,5 \%$.
Nota-se que a má distribuição do consumo dos alimentos constitui, a nosso ver, um fator importante a ser considerado. Também pode-se observar no contato com a comunidade, condições ecológicas adversas, que limitam a disponibilidade regular dos produtos da pesca e da lavoura. Instabilidades metereológicas e eventos como enchentes, causam danos às plantações e dificultam a pesca.

Entre os diaristas de Iguape a porcentagem de adequação do consumo em minerais e vitaminas, foi deficiente na quase totalidade das famílias (Tabela 2) aliás, como ocorreu em Pontal do Ribeira. Quanto às proteínas, 52,0\% das famílias as consumiram em níveis abaixo de $100,0 \%$ e $32,6 \%$ acima de $120,0 \%$. Aqui também há má distribuição desse nutriente. Sendo esses dados levantados na temporada da pesca, provavelmente o alto consumo de proteínas deva-se aos pescadores que podem usar o peixe na alimentação com mais facilidade.

Em Vila de Icapara houve condições mais favoráveis na distribuição e na disponibilidade de proteínas e calorias, embora, como nos casos anteriores, a população careça dos demais nutrientes. As proteínas e calorias foram consumidas em níveis abaixo de $100,0 \%$ de adequação por $35,4 \%$ das famílias e em níveis acima de $120,0 \%$ em $58,8 \%, 47,0 \%$ consumiram calorias em níveis acima de $120,0 \%$ (Tabela 3 ). Nesta comunidade houve maior consumo de proteínas e de calorias do que nas anteriores.

Nesta localidade as condições ecológicas não são adversas como em Pontal do Ribeira. A população não se queixou de enchentes e de danos na lavoura e na temporada de pesca há relativa fartura de pescado. Pesca-se, em grupos de três ou quatro pessoas, apenas peixe de rio, o que traz maior rendimento na produção. 
MARTINS, I. S. - Estudo da situação sócio-econômica e do consumo de nutrientes em comunidades do Vale do Ribeira, são Paulo, Braisil. Rev. Saúde públ., S. Paulo, 6: 199-209, 1972.

T A B EL A 1

Porcentagem de Adequação dos Nutrientes (Vitamina A, Tiamina, Riboflavina, Vitamina C Niacina, Cálcio; Ferro, Proteínas) e Calorias em Pontal do Ribeira em 1969.

\begin{tabular}{|c|c|c|c|c|c|c|c|c|c|}
\hline $\begin{array}{l}\text { No da } \\
\text { Familia }\end{array}$ & 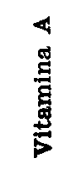 & 鸪 & 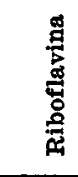 & 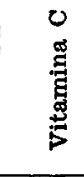 & 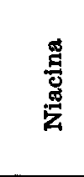 & 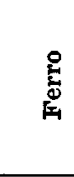 & $\frac{9}{0}$ & 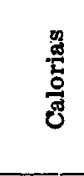 & 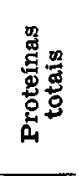 \\
\hline $\begin{array}{l}1 \\
2 \\
4 \\
5 \\
6 \\
8 \\
9 \\
10 \\
11 \\
12 \\
13 \\
14 \\
15 \\
16 \\
17 \\
18 \\
20 \\
21 \\
22 \\
23 \\
24 \\
25 \\
26 \\
27 \\
28 \\
29 \\
30 \\
31 \\
32 \\
33 \\
34 \\
35 \\
36 \\
38 \\
39 \\
40 \\
44 \\
45 \\
46 \\
47 \\
48 \\
49 \\
50 \\
51 \\
52 \\
53 \\
54 \\
55 \\
56 \\
57 \\
58 \\
60 \\
61 \\
62 \\
63 \\
64\end{array}$ & $\begin{array}{c}32,4 \\
0,1 \\
0,2 \\
0,3 \\
0 \\
3,3 \\
0 \\
0 \\
0 \\
0,4 \\
0 \\
0 \\
4,3 \\
0 \\
0 \\
0 \\
16.1 \\
0,1 \\
0,1 \\
0 \\
0 \\
0 \\
0,1 \\
2,2 \\
0,4 \\
01 \\
0,1 \\
8,7 \\
21,1 \\
0,1 \\
0 \\
0\end{array}$ & $\begin{array}{r}794 \\
58,5 \\
38,8 \\
65,4 \\
59,3 \\
49,5 \\
30,3 \\
32,8 \\
21,2 \\
15,7 \\
7,6 \\
27,3 \\
30,0 \\
16,9 \\
86,7 \\
68,0 \\
36,8 \\
62,1 \\
18,4 \\
30,6 \\
47,8 \\
78,1 \\
37,4 \\
35,1 \\
70,0 \\
110,0 \\
30,9 \\
30,2 \\
149 \\
83,3 \\
12,1 \\
71,0 \\
15,2 \\
36,9 \\
19,4 \\
112,1 \\
19,7 \\
22,7 \\
26,3 \\
11,3 \\
49,4 \\
51,0 \\
30,5 \\
37,1 \\
47,1 \\
14,1 \\
37,6 \\
7,5 \\
42,8 \\
32,5 \\
10,9 \\
42,2 \\
42,2 \\
11,7 \\
104,0 \\
46,8\end{array}$ & $\begin{array}{r}43,1 \\
29,0 \\
15,0 \\
38,7 \\
10,3 \\
32,0 \\
21,2 \\
18,8 \\
24,0 \\
12,2 \\
9,6 \\
23,9 \\
15,7 \\
11,2 \\
29,5 \\
12,6 \\
19,6 \\
65,3 \\
12,4 \\
15,6 \\
22,7 \\
31,7 \\
18,6 \\
18,8 \\
36,5 \\
95,0 \\
20,5 \\
22,1 \\
18,5 \\
132,0 \\
16,4 \\
28,2 \\
10,6 \\
18,2 \\
15,9 \\
78,8 \\
21,1 \\
16,1 \\
31,5 \\
16,0 \\
30,2 \\
27,7 \\
18,0 \\
16,4 \\
24,8 \\
7,2 \\
32,9 \\
8,1 \\
31,3 \\
24,4 \\
16,3 \\
10,9 \\
29,1 \\
4,1 \\
34,8 \\
31,4\end{array}$ & 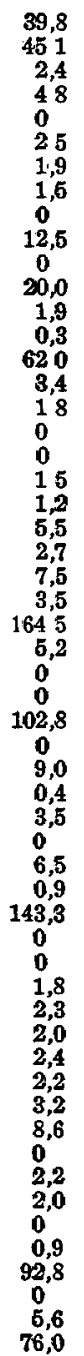 & $\begin{array}{r}135,0 \\
109,0 \\
53,0 \\
158,3 \\
43,3 \\
128,3 \\
110,0 \\
101,9 \\
195,0 \\
41,9 \\
45,9 \\
111,3 \\
74,8 \\
73,2 \\
85,3 \\
43,3 \\
88,7 \\
250,0 \\
81,9 \\
72,3 \\
58,0 \\
122,0 \\
68,2 \\
62,8 \\
111,2 \\
322,7 \\
115,5 \\
123,0 \\
95,5 \\
221,0 \\
84,2 \\
90,5 \\
59,5 \\
78,8 \\
90,2 \\
189,1 \\
103,8 \\
72,9 \\
172,3 \\
74,5 \\
1128,7 \\
110,0 \\
77,8 \\
67,0 \\
94,6 \\
59,4 \\
86,0 \\
54,5 \\
169,1 \\
114,0 \\
48,4 \\
53,1 \\
117,0 \\
40,9 \\
165,0 \\
78,6\end{array}$ & $\begin{array}{r}95,5 \\
113,8 \\
84,2 \\
158,3 \\
35,8 \\
73,8 \\
48,6 \\
39,4 \\
79,0 \\
58,9 \\
47,6 \\
45,5 \\
64,6 \\
42,7 \\
80,6 \\
50,8 \\
65,7 \\
152,6 \\
40,9 \\
62,1 \\
52,4 \\
142,5 \\
70,5 \\
46,6 \\
125,3 \\
201,5 \\
59,6 \\
61,5 \\
53,5 \\
470,0 \\
67,0 \\
189,6 \\
42,1 \\
67,0 \\
51,9 \\
51,9 \\
147,6 \\
62,6 \\
58,3 \\
52,8 \\
71,6 \\
52,7 \\
97,0 \\
90,8 \\
45,2 \\
35,2 \\
70,0 \\
34,4 \\
107,7 \\
56,4 \\
\mathbf{3 7 ,}, 8 \\
34,2 \\
65,2 \\
35,8 \\
161,0 \\
72,3\end{array}$ & $\begin{array}{r}10,8 \\
23,6 \\
13,8 \\
42,3 \\
10,6 \\
20,7 \\
12,1 \\
115,6 \\
33,3 \\
12,3 \\
20,6 \\
12,3 \\
127,9 \\
11,8 \\
21,8 \\
8,3 \\
13,3 \\
52,6 \\
11,7 \\
13,3 \\
19,3 \\
21,0 \\
17,1 \\
8,5 \\
27,7 \\
66,2 \\
12,9 \\
10,6 \\
20,1 \\
81,0 \\
27,5 \\
33,5 \\
11,6 \\
16,3 \\
10,8 \\
31,4 \\
27,2 \\
14,9 \\
22,1 \\
22,7 \\
16,1 \\
21,5 \\
9,2 \\
12,6 \\
18,3 \\
9,9 \\
17,0 \\
11,0 \\
28,0 \\
19,4 \\
9,3 \\
9,5 \\
21,3 \\
5,3 \\
25,2 \\
18,0\end{array}$ & 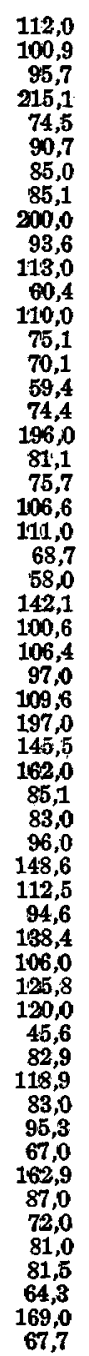 & $\begin{array}{r}139,1 \\
90,6 \\
78,6 \\
182,2 \\
70,0 \\
143,3 \\
110,1 \\
92,1 \\
129,0 \\
47,6 \\
54,8 \\
100,0 \\
74,1 \\
57,1 \\
94,8 \\
66,3 \\
91,5 \\
327,1 \\
58,7 \\
69,4 \\
38,5 \\
131,8 \\
62,8 \\
62,5 \\
113,0 \\
175,8 \\
118,1 \\
106,5 \\
98,0 \\
356,2 \\
93,5 \\
129,7 \\
56,1 \\
76,6 \\
82,4 \\
112,7 \\
222,1 \\
59,8 \\
159,0 \\
85,8 \\
141,2 \\
137,8 \\
77,1 \\
76,8 \\
113,3 \\
28,9 \\
94,3 \\
40,1 \\
164,7 \\
130,5 \\
52,8 \\
54,7 \\
125,4 \\
15,6 \\
148,6 \\
99,2\end{array}$ \\
\hline
\end{tabular}


MARTINS, I. S. - Estudo da situação sócio-econômica e do consumo de nutrientes em comu. nidades do Vale do Ribeira, São Paulo, Brasil. Rev. Saúde públ., S. Paulo, 6: 199-209, 1972.

T A B E I, A 2

Porcentagem de Adequação do Consumo dos Nutrientes (Vitamina A, Tiamina, Riboflavina, Niacina, Vitamina C, Cálcio, Ferro, Proteinas) e Calorias, entre os Diaristas de Iguape, em 1969.

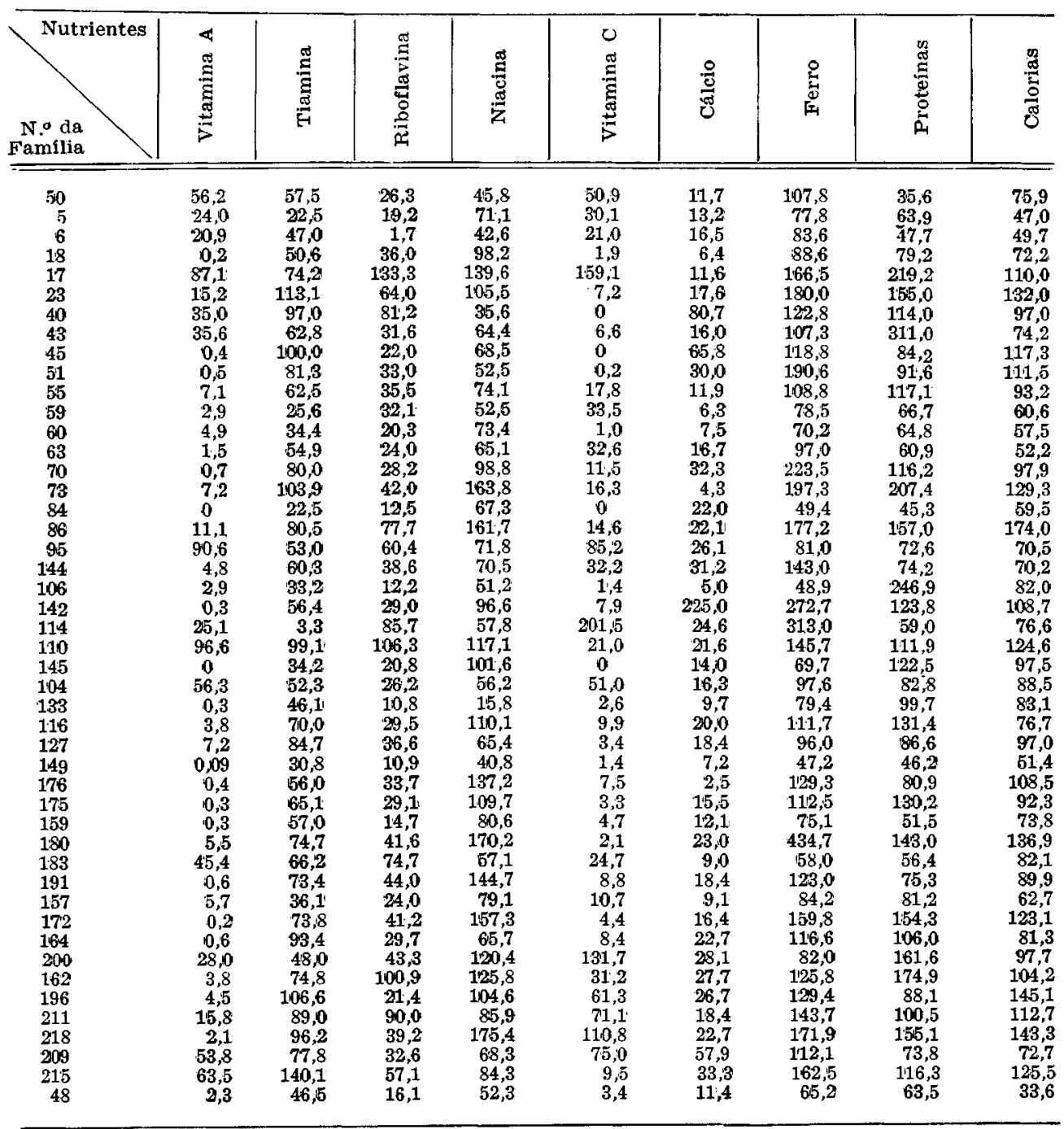


MARTINS, I. S. - Estudo da situação sócio-econômica e do consumo de nutrientes em comunidades do Vale do Ribeira, São Paulo, Brasil. Rev. Saúde públ., S. Paulo, 6: 199-209, 1972.

T A B E L A 3

Porcentagem de Adequação dos Nutrientes (Vitamina A, Tiamina, Riboflavina, Vitamina C, Niacina, Cálcio, Ferro, Proteinas) e Calorias em Vila de Icapara, em 1969.

\begin{tabular}{|c|c|c|c|c|c|c|c|c|c|}
\hline $\begin{array}{l}\text { N.o da } \\
\text { Framilia }\end{array}$ & 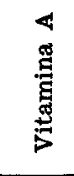 & 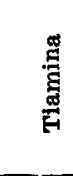 & 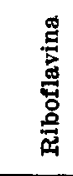 & 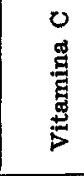 & 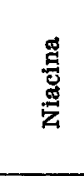 & 号 & $\frac{8}{8}$ & & 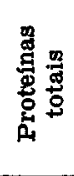 \\
\hline $\begin{array}{r}26 \\
74 \\
104 \\
27 \\
52 \\
13 \\
15 \\
43 \\
86 \\
90 \\
85 \\
29 \\
47 \\
16 \\
28 \\
5 \\
1 \\
114 \\
116 \\
113 \\
130 \\
73 \\
125 \\
96 \\
21 \\
63 \\
68 \\
61 \\
67 \\
71 \\
11 \\
10 \\
70 \\
75\end{array}$ & $\begin{array}{r}8,8 \\
5,7 \\
4,6 \\
0,3 \\
6,0 \\
15,4 \\
288,0 \\
14,6 \\
6,5 \\
60,0 \\
1,9 \\
20,7 \\
0,7 \\
0,3 \\
0,2 \\
43,7 \\
32,4 \\
1,0 \\
2,2 \\
0,3 \\
3,3 \\
0,6 \\
0,4 \\
3,5 \\
0,0 \\
0,1 \\
0,1 \\
1,0 \\
0,5 \\
0,2 \\
0,2 \\
81,8 \\
0,5 \\
0,3\end{array}$ & $\begin{array}{r}41,5 \\
62,0 \\
66,6 \\
70,8 \\
51,9 \\
23,2 \\
110,0 \\
31,9 \\
20,5 \\
55,3 \\
71,2 \\
72,3 \\
86,2 \\
54,3 \\
46,4 \\
88,0 \\
72,3 \\
16,8 \\
55,0 \\
100,0 \\
86,9 \\
82,5 \\
49,4 \\
89,5 \\
68,9 \\
17,8 \\
49,5 \\
132,0 \\
85,4 \\
98,6 \\
32,5 \\
71,6 \\
130,0 \\
63,1\end{array}$ & $\begin{array}{r}12,8 \\
55,2 \\
36,8 \\
32,9 \\
31,2 \\
20,5 \\
47,0 \\
7,1 \\
22,9 \\
70,8 \\
36,9 \\
68,4 \\
45,0 \\
19,4 \\
13,2 \\
36,0 \\
54,3 \\
16,7 \\
39,1 \\
35,7 \\
42,1 \\
33,1 \\
21,7 \\
57,9 \\
21,0 \\
13,9 \\
26,7 \\
51,3 \\
46,4 \\
56,0 \\
8,2 \\
21,1 \\
43,8 \\
36,4\end{array}$ & 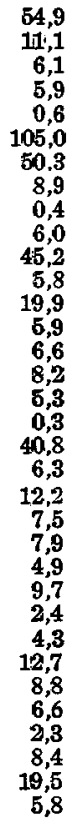 & $\begin{array}{r}77,8 \\
118,0 \\
84,9 \\
357,0 \\
119,0 \\
134,0 \\
141,0 \\
128,0 \\
47,2 \\
81,3 \\
122,0 \\
170,0 \\
1151,0 \\
101,0 \\
69,3 \\
143,0 \\
206,0 \\
78,0 \\
102,0 \\
184,0 \\
147,0 \\
163,0 \\
79,5 \\
157,0 \\
141,0 \\
71,4 \\
85,9 \\
151,0 \\
154,0 \\
179,0 \\
64,8 \\
108,0 \\
141,0 \\
138,0\end{array}$ & $\begin{array}{r}64,4 \\
115,3 \\
99,0 \\
149,3 \\
98,2 \\
92,6 \\
172,4 \\
74,7 \\
74,6 \\
89,7 \\
112,9 \\
1106,7 \\
154,6 \\
133,6 \\
81,3 \\
171,1 \\
173,9 \\
57,9 \\
149,0 \\
139,8 \\
126,2 \\
197,4 \\
99,5 \\
124,2 \\
119,8 \\
49,2 \\
80,2 \\
209,0 \\
139,7 \\
182,0 \\
71,3 \\
94,6 \\
140,0 \\
119,4\end{array}$ & $\begin{array}{r}20,2 \\
33,7 \\
18,9 \\
35,7 \\
16,2 \\
14,5 \\
37,4 \\
29,6 \\
24,7 \\
20,5 \\
28,8 \\
25,9 \\
35,6 \\
22,5 \\
11,8 \\
28,4 \\
49,3 \\
6,9 \\
34,6 \\
26,0 \\
24,4 \\
31,2 \\
22,7 \\
38,8 \\
22,7 \\
14,0 \\
13,6 \\
35,7 \\
28,4 \\
43,6 \\
12,2 \\
23,7 \\
27,2 \\
19,7\end{array}$ & $\begin{array}{r}147,8 \\
97,4 \\
90,0 \\
86,5 \\
136,1 \\
84,7 \\
150,9 \\
152,5 \\
146,5 \\
92,3 \\
73,6 \\
138,4 \\
125,5 \\
101,5 \\
84,9 \\
173,7 \\
134,2 \\
63,5 \\
151,8 \\
186,5 \\
135,2 \\
105,6 \\
107,8 \\
122,0 \\
101,9 \\
84,6 \\
90,4 \\
119,2 \\
149,7 \\
150,0 \\
87,6 \\
81,6 \\
130,2 \\
104,9\end{array}$ & $\begin{array}{r}80,5 \\
138,0 \\
93,2 \\
74,2 \\
101,0 \\
65,9 \\
184,5 \\
170,7 \\
41,3 \\
96,6 \\
137,1 \\
149,3 \\
191,3 \\
133,4 \\
64,1 \\
198,4 \\
169,8 \\
55,1 \\
194,8 \\
145,7 \\
180,8 \\
146,4 \\
97,7 \\
193,9 \\
141,0 \\
79,5 \\
88,6 \\
195,9 \\
200,7 \\
225,1 \\
67,4 \\
141,5 \\
189,7 \\
104,9\end{array}$ \\
\hline
\end{tabular}

2 - MATERIAL E METODOS

\section{1 - Levantamento da renda média familiar e renda média anual "per capita"}

As dificuldades de um levantamento de renda em economias de subsistência, onde a produção diária é irregular, obrigam-nos a colher o maior número possível de informaçōes referentes à receita monetária e não monetária, assim como a fazer uma série de pressuposições, visando uma aproximação, a mais fidedigna possível, da realidade.

Contamos, para esse levantamento, com os dados do inquérito alimentar, que nos forneceu as quantidades exatas de cada alimento consumidos em 24 horas por familia.

\section{Vila de Icapara}

a) Partimos da pressuposição de que, em média, cada uma das famílias consome alimentos nas quantidades medidas no dia do inquérito alimentar; durante todos os dias do ano. Calculou-se o consumo anual, por familia, de peixe e de farinha de mandioca.

b) Estimou-se o valor do combustível gasto em um ano, através de número 
MARTINS, I. S. - Estudo da situaçăo sócio-econômica e do consumo de nutrientes em comunidades do Vale do Ribeira, São Paulo, Brasil. Rev. Saúde públ., S. Paulo, 6: 199-209, 1972.

modal de achas de lenha gastas em um dia pelas famílias.

c) Estimou-se o valor locativo da residência para um ano ( $1 \%$ do valor da propriedade multiplicado por 12).

d) Calculou-se a receita do último ano obtida pela venda dos produtos da pesca e do consumo e venda dos produtos da lavoura (com exceção da farinha de mandioca já computada em a).

A soma dos valores obtidos em a), b), c), e d), nos dá a renda total de cada família.

Procedeu-se supletivamente outra forma de cálculo através da receita da última semana, obtida pela venda dos produtos da pesca e do consumo de alimentos e combustível. A soma desses valores foi multiplicada por 26 (número de semanas de temporada de pesca). Para o período entre-safra (26 semanas) calculou-se a renda pelo consumo de alimentos e o gasto de combustível. Somou-se a esses valores a estimativa do valor locativo da residência.

Obteve-se assim, a renda total por família (Cr\$1.668,00, US\$ 403.00 anuais), que dividida pelo número de pessoas da amostra, nos dá a renda média "per capita” anual (Cr\$374,00, US\$90.00).

\section{Pontal do Ribeira}

Em Pontal do Ribeira, sendo a pesca a atividade principal do ano todo, a melhor maneira de calcular a renda em nossa opinião, foi a seguinte:

a) Calculou-se para a semana anterior ao Inquérito Alimentar, o consumo de peixe, lenha, farinha de mandioca $e$ a receita obtida pela venda do peixe $e$ de pequenos serviços. Multiplicou-se a soma desses valores por 52 (número de semanas do ano).

b) Somou-se ao valor obtido em a), a receita do último ano obtida pela ven- da e consumo dos produtos da lavoura e acrescentou-se a estimativa do valor locativo anual da residência. Chegou-se assim a renda total por familia por ano. A soma das rendas totais dividida pelo número de famílias da amostra deu a renda média anual familiar (Cr\$1.984,00, US\$ 480.00), que, dividida pelo número de pessoas da amostra forneceu a renda média anual "per capita" (Cr\$308,00, US\$ 74.00).

\section{Diaristas de Iguape}

Para os diaristas de Iguape, excetuando-se o ganho devido ao valor locativo da residência, a renda, na sua quase totalidade, provém da receita diária em dinheiro.

Para os pescadores calculou-se:

a) a renda média por semana e multiplicou-se esse valor por 26 (número de semanas do período de pesca).

b) Para o período entre-safra, em que o mercado de trabalho diminui, fizemos a pressuposição de que o ganho, nesse período, daria exclusivamente para a compra dos alimentos básicos, e que, em média, consumiriam por dia as quantidades medidas no dia do inquérito alimentar. Calculou-se então a renda de uma semana e multiplicou-se esse valor por 26 (número de semanas do período entre safra). A soma de a) e b) juntouse a estimativa do valor locativo da residência e tivemos assim a renda total anual por familia.

Para os não pescadores, calculou-sè a renda média por semana e multiplicouse $o$ valor obtido por 52 (número de semanas do ano). Somou-se ao valor obtido a estimativa do valor locativo da residência e obtivemos a renda total anual por famflia.

Somando-se as rendas totais das famílias e dividindo-se pelo número delas, tivemos a renda média anual familiar 
MARTINS, I. S. - Estudo da situação sócio-econômica $\theta$ do consumo de nutrientes em comunidades do Vale do Ribeira, São Paulo, Brasil. Rev. Saúle públ., S. Paulo, 6: 199-209, 1972.

(Cr\$1.791,00, US\$433.00) que dividida pelo número de pessoas da amostra nos dá a renda "per capita" média (Cr\$399,00, US\$96.00).

As rendas "per capita" dessas três comunidades estão na faixa da renda "per capita" de 50,0\% da população da América Latina 4.

\section{3 - RESULTADOS E COMENTÁRIOS}

Passamos a avaliar pelo coeficiente de correlação Pearson, as eventuais relações das variáveis econômicas com a porcentagem de adequação do consumo de proteína e de calorias e com o número de pessoas da casa.
As variáveis econômicas estudadas foram: a renḍa média "per capita" por família; a renda total anual por família e a porcentagem de renda monetária/ renda total por família.

No que se refere a Pontal do Ribeira, vimos pela Tabela 4, que a renda total por familia e a porcentagem de renda monetária/renda total dão uma correlação positiva com o número de pessoas da casa. Famílias maiores contam com maiores recursos individuais para o trabalho.

Não houve correlação entre a adequação do consumo de proteínas e de calorias com a renda total e renda média

TA BELA 4

Valores de coeficiente de correlação de Pearson, para Pontal do Ribeira, diaristas de Iguape e Vila de Icapara, em 1969.

\begin{tabular}{|c|c|c|c|}
\hline Comunidade & $\begin{array}{r}\text { Pontal do } \\
\text { Ribeira }\end{array}$ & $\begin{array}{l}\text { Diaristas } \\
\text { de Iguape }\end{array}$ & $\begin{array}{l}\text { Vila de } \\
\text { Icapara }\end{array}$ \\
\hline $\begin{array}{l}\text { Nivel de significancia } \\
\text { e graus de liberdade }\end{array}$ & $\begin{array}{l}\alpha=5 \% \\
10 . \text { g.1. }\end{array}$ & $\begin{array}{c}\alpha=5 \% \\
40 . \text { g.1. }\end{array}$ & $\begin{array}{c}\alpha=5 \% \\
32 . \text { g.1. }\end{array}$ \\
\hline $\begin{array}{l}\text { Renda média anual "per capita" } X \text { adequação do } \\
\text { consumo de proteinas }\end{array}$ & $-0,04753$ & $+0,4130$ & $+0,4387$ \\
\hline $\begin{array}{l}\text { Renda total anual por familia } \mathrm{X} \text { adequação do } \\
\text { consumo de proteínas }\end{array}$ & +0.04675 & $+0,09329$ & $+0,1371$ \\
\hline $\begin{array}{l}\text { Renda média anual "per capita" } \mathrm{X} \text { adequação do } \\
\text { consumo de calorias }\end{array}$ & $+0,06434$ & $+0,3761$ & $+10,2436$ \\
\hline $\begin{array}{l}\text { Renda total anual por familia } X \text { adequação do } \\
\text { consumo de calorias }\end{array}$ & $-0,3128$ & $-0,04759$ & $-0,02031$ \\
\hline $\begin{array}{l}\text { Porcentagem de renda monetária / renda total } \mathbf{x} \\
\text { consumo de calorias }\end{array}$ & $-0,3129$ & * & $-0,09108$ \\
\hline $\begin{array}{l}\text { Renda total anual por familia } \mathrm{X} n 0^{\circ} \text { de pessoas da } \\
\text { casa. }\end{array}$ & $+0,7021$ & $+0,4374$ & $+0,3134$ \\
\hline $\begin{array}{l}\text { Porcentagem de renda monetária / renda total } x \\
\text { n. } .^{\circ} \text { de pessoas da casa. }\end{array}$ & $+0,3729$ & * & $+0,08803$ \\
\hline $\begin{array}{l}\text { Porcentagem de renda monetária/renda total } \mathrm{X} \\
\text { consumo de proteínas }\end{array}$ & $-0,8865$ & * & $-0,006021$ \\
\hline
\end{tabular}
* Batas correlaçóes não teriam sentido para os diaristas de Iguape, porque estes recebem,
quase que exclusivamente, renda monetária 
MARTINS, I. S. - Fistudo da situação sócio-económica e do consumo de nutrientes em comunidades do Vale do Ribeira, săo Paulo, Brasil. Rev. Saúde publ., S. Paulo, 6: 199-209, 1972.

"per capita" por família. clássico encontrar-se em outro tipo de economia, uma correlação positiva entre nivel econômico e consumo de proteínas, que é um nutriente e alto custo; acontece $o$ contrário com o consumo de calorias porque os nutrientes que contribuem com a maior taxa calórica na nossa dieta (hidrato de carbono) são de baixo custo.

A correlação inversa entre a porcentagem de renda monetária/renda total e o consumo de proteínas $(r=-0,8865$, a 5\%; 19 g. 1.) vem confirmar o que já pressupúnhamos, que as famílias que vendem mais são via de regra, as que consomem menos.

Nesta comunidade, $57,1 \%$ das famílias apresentam consumo de proteínas abaixo do nível considerado adequado (100,0\% de adequação) e em calorias $55,3 \%$ delas (Tabela 1). Essa porcentagem de familias com consumo insuficiente é consequiência, como vimos, das condições ecológicas adversas, do alto custo do peixe (Cr\$ 1,00 a Cr\$2,00 o quilo) e da necessidade de venda dos produtos. Notase na comunidade um contato intenso com a cidade através de rádio, o que contribui para o surgimento de novas necessidades que levaram a população a se interessar pela aquisição de dinheiro através da venda de seus produtos.

Entre os diaristas de Iguape encontrou-se uma correlação positiva entre 0 nível econômico da família e a adequa. ção do consumo de proteínas e de calorias, o que era de se esperar nesse centro urbano. Existem certas peculiaridades em Iguape que a diferem da maioria dos centros urbanos. Aqui as proteínas de origem animal, que provém em grande parte do peixe (manjuba), de baixo custo ( $\operatorname{Cr} \$ 0,50$ o quilo), são tão acessíveis quanto os alimentos ca16ricos.

Nesta comunidade $53,1 \%$ das famílias
(Tabela 2), apresentaram consumo abaixo de $100,0 \%$ de adequação em proteínas e 70,4\% em calorias.

Houve correlação positiva entre a renda total familiar e o número de pessoas da casa ( $r=+0,4374$ para $a=5 \%, 40$ graus de liberdade).

Para Vila de Icapara houve uma correlação positiva entre renda média "per capita"/família e a adequação do consumo de proteínas. Sendo uma economia de subsistência e tendo sido estes dados levantados na temporada de pesca, quando há grande disponibilidade de peixe, é mais verdadeiro interpretar essa correlação positiva como resultado do fato de que maior produção leva a maior consumo e venda.

A porcentagem de renda monetária/ renda total por família não mostra correlação com o número de pessoas da casa. Talvez isto seja explicável pelo fato de que sendo os pescadores assalariados, apenas os chefes de familia e os filhos maiores (a comunidade conta com poucos jovens acima de 15 anos), sejam aceitos como empregados. Na lavoura, porém, toda a família participa, desde as mulheres até as crianças. Nessa comunidade, como vimos, há maior disponibilidade quer de produtos da lavoura, quer daqueles da pesca, do que em Pontal do Ribeira ou entre os diaristas de Iguape. A população de Icapara adquire a manjuba às vêzes gratuitamente ou abaixo custo ( $\mathrm{Cr} \$ 0,25$ o quilo).

A porcentagem de familias com consumo insuficiente em proteínas e calorias foi de $35,3 \%$, proporção bastante menor do que nas outras duas comunidades, (Tabela 3). possivel no periodo entre-safra, haja maior porcentagem de familias com consumo abaixo do valor considerado adequado.

Em Vila de Icapara o contato com os centros urbanos, é então intenso como em Pontal do Ribeira, entretanto, a grande vantagem dos habitantes dessa 
MARTINS, I. S. - Fstudo da situaçăo śbio-econômica e do consumo de nutrientes em comunidades do Vale do Ribeira, Săo Paulo, Brasil, Rev. Saúde públ., S. Paulo, 6: 199.209, 1972.

comunidade é a mais fácil aquisição de dinheiro por se tornarem assalariados na temporada de pesca.

f possível que a adequação do consumo de nutrientes tenha maior dependência com o número de pessoas da familia do que com a renda total da família, uma vez que não obtivemos, em nenhum caso, uma correlação positiva significante entre renda total da família e consumo de proteínas e calorias.

A análise dessas três comunidades demonstra que outros fatores, além do econômico, atuam de maneira também relevante na adequação do consumo dos nutrientes. $O$ desconhecimento do valor da alimentação, por exemplo, foi um fator de grande importância para o consumo deficiente de alimentos ricos em vitaminas e minerais, que seriam de fácil obtenção nessas comunidades que possuem terrenos suficientes para o cultivo. Pôde-se notar que os fatores ecológicos e a má distribuição dos gêneros alimenticios entre as familias, influiram no baixo consumo de alimentos em expressiva porção da população. Encontrou-se, por exemplo, em Pontal, 32,7\% das famílias com consumo de proteína acima de $120,0 \%$ de adequação e $57,1 \%$ com consumo abaixo de $100,0 \%$. Este desequilf́brio na distribuição dos alimentos foi encontrado entre os diaristas de Iguape e em menor proporção em Vila de Icapara, por tratar-se de um período de relativa fartura.

O estudo dessas três comunidades comprova, mais uma vez, a multicausalidade do problema má alimentação, que leva, consequientemente, à desnutrição. Devido a essa multicausalidade é um problema que deve ser abordado mediante a ação coordenada e simultânea das áreas da economia, agricultura, educação, saúde e outras que atuam na comunidade, através de planos a curto, médio e longo prazo, aproveitando, na medida do possível, os recursos locais.

CON CLUSOES

a) As comunidades estudadas consumiram em quantidades deficientes os alimentos ricos em vitaminas e minerais.

b) Nas Vilas de Icapara e Pontal do Ribeira, comunidades que vivem da pesca e agricultura de subsistência, a ađequação do consumo de proteínas e de calorias não mostrou correlação com 0 nível econômico da familia.

c) $\mathrm{Na}$ comunidade dos diaristas de Iguape, houve uma correlação positiva entre o nível econômico da familia e a adequação do consumo de proteínas e de calorias. Provavelmente, deve-se ao fato de estarem inseridas em um centro urbano o que torna necessária a compra desses gêneros.

d) A renda total familiar foi maior em domicilios com maior número de pessoas. O mesmo não ocorreu com a adequação do consumo de proteínas e de calorias, em parte devido à necessidade de venda dos produtos necessários à alimentação para a compra de bens de consumo provindas dos centros urbanos. 
MARTINS, I. S. - Estudo da situação sócio-económica e do consumo de nutrientes em comunidades do Vale do Ribeira, São Paulo, Brasil. Rev. Saúde pübl., S. Paulo, 6: 199-209, 1972.

\section{RSPSP-132}

MARTins, I. S. - [Socio-economic aspects and the nutrients consumption in communities of the Vale do Ribeira, São Paulo State, Brazil]. Rev. Saúde públ., S. Paulo, 6:199-209, 1972.

Summary: There has been done a raise about the annual family total income and also the annual family revenue "per capita" among three communities in the Vale do Ribeira, situated in South seaside part of S. Paulo State. The necessity of adapting the investigation method to the local living condition, in order to obtain data according to reality was emphasized. Two of them, Vila de Icapara and Pontal do Ribeira, have subsistence economy and their population depend on fishing and agriculture in their living the third one is composed of the Iguape's transient workers that live in an urbain center of Iguape. Also in these three communities a food survey has been done has been calculated the adequacy of nutrients and calories consumption among the families. It was calculated the Pearson's correlation coeficient among economical variants and adequacy of proteins and calories consumption, and the conclusions was the following: a) In the two communities, Vila de Icapara and Pontal do Ribeira, which have subsistence econo$m y$, there wasn't a correlation between the protein and calories consumption and the family economic level. b) In the Iguape's transient workers community, there was a positive correlation between the protein and calories consumption and the family economic level.

UNITERMS: Socio-economic survey*; Nutrients, consumption*; Food survey ${ }^{*}$.

\section{REFERENCIAS BIBLIOGRAFICAS}

1. ENCICLOPEDIA DOS MUNICIPIOS BRASILEIROS. Rio de Janejro IBGE, 1957. v. 28.

2. FAO. Committee on Calories Requirements. - Calorie requirements. Roma, 1050. (Report n. 6).

3. INSTITUTO DE CENTRO AMERICA $\mathbf{Y}$ PANAMA (INCAP). Recomendaciones nutricionales para las poblaciones de Centro América y Panamá. Bol. Ofic. sanit. panamer., (supl. 1): 119-29, 18153.

4. MARCONDES-RESTAT, F. - Alimentos $y$ nutrición en el desarrollo econômico $y$ social de América Latina. [Apresentado na Conferencia sôbre Educación Nutricional en el Desarrollo de América Latina. Washington, DC. 1966.]

5. SAO PAULO. Departamento de Aguas e Energia Elétrica. Serviço do Vale Ribeira - Plano de desenvolvimento do Vale do Ribeira e litoral sul. São Praulo, Brasconsult, 1966 . v. 1, p. 27-33.

6. Ibdem, v, 2 .

Recobido para publicạăio em 31-5-1971

Aprovado para publicacão em 25-4-1972 